\title{
Beloved and Julia Kristeva's The Semiotic and The Symbolic
}

\author{
Camelia Talebian Sadehi \\ Department of Foreign Languages, University of Amin, Isfahan, Iran \\ Email:CCml_talebian@yahoo.com
}

\begin{abstract}
One of the most important African-American female novelists of the $20^{\text {th }}$ century is Toni Morrison. Her novels consider the blight of the black people in American history. This article intends to focus on Morrison's Beloved in the light of Julia Kristeva's theory of the semiotic and the symbolic. As Morrison has written a poetic-fictional text, Kristeva's the semiotic and the symbolic are applicable in Morrison's Beloved.
\end{abstract}

Index Terms-Beloved, the semiotic, the symbolic, black people, poetic-fictional text

\section{INTRODUCTION}

Julia Kristeva is concerned with the subject's identity. She believes that the subject can gain his/her identity through language. When s/he expresses her/his intentions, either directly or indirectly, s/he can claim her/his subjectivity. Beloved is the good example for Kristeva's theories of subjectivity, as it deals with the questions of slavery and the way the blacks cope with their problems. Toni Morrison wrote Beloved in 1987. Beloved is a historical novel based on Margaret Garner's true-life story. Margaret Garner was a slave and she did not wish her children to live as slaves as she did; therefore, she decided to murder them rather than to see them as slaves. Garner emphasizes that she "would much rather kill them at once and thus end their suffering, than have them taken back to slavery and be murdered by piecemeal" (Peterson, 2008, p. 17). She had killed her two-year-old daughter and Morrison selects her story, but modifies it based on her purpose. She changes "names, dates, details and narrative outcomes" of Garner's story (ibid. 19).

Morrison selects Garner's story to describe the painful slaves' experience and their life after abolition of slavery. She recognizes that unlike whites, blacks were silent throughout American history and literature; therefore, she intends to give blacks voice to express their pain in her novels. She challenges the dominant white and Eurocentric discourse by referring to the African and Afro-American presence in the U.S. literary history (Jung, 2009, p. 41). In fact, Morrison enlivens the "presence of black people by critiquing their suppressed absence from U.S. literary history" (2004, p. 42).

Beloved conveys the unrecorded, brutalized slaves' experience and the way they cope with their past. Morrison displays the effect of slavery despite the passage of many years after abolishment of slavery(Mousey, 2010, p. 48); one can still conceive blacks' otherness even in the postmodern age. Morrison heals the chronic infectious wound of slavery through writing about slavery and its aftermaths; moreover, she shows the "interior life of people" (Amian, 2008, p. 120). This article intends to apply Julia Kristeva's theory of the semiotic and the symbolic to Beloved and discuss how characters use language to gain self-realization.

\section{THE SEMIOTIC AND THE SYMbolic}

In Kristeva's terms, the semiotic and the symbolic refer to two interdependent aspects of language. The semiotic is defined as the matriarchal aspect of language that shows the speaker's inner drives and impulses. These unconscious drives manifest themselves in character's tone, their rhythmical sentences and the images they use in order to express what they want to convey. The semiotic aspect is repressed not only by society but also by the patriarchal aspect of language that Kristeva calls the symbolic. In other words, one should realize that "in Kristevan schemes, the social is always oppressive" (Jones, 1984, p. 58).

The symbolic is the rule-governed aspect of language, which shows itself in the grammatical structures and syntactic structures. Although the semiotic and the symbolic aspects of language oppose one another in their nature, they complete each other in language. The speaker's speech is meaningful when both the semiotic and the symbolic are together. As Sutcliffe emphasizes, "the semiotic and symbolic as opposites" are "necessary for both each other and the subject in whom they are combined" (2003, p. 337). Besides, "no text, however radical, is purely semiotic" but rather "the semiotic always manifests itself within the symbolic" (Sabo, 2010, p. 59).

As Morrison's style is lyrical, and her prose is poetical, the semiotic aspect of language is manifest in her work. Besides, the grammatical structure of her sentences makes it possible to focus on the semiotic and the symbolic as the two interdependent aspects of language. Morrison's novel is musical, and her language "breathes... as if it has to jump off the page. So we read it as poetry" (Iasevoli, 1998, p. 61). In fact, Afro-American slaves and ex-slaves can reaffirm 
their identity just through musical expressions. They survive and heal their wounded subjectivity through music. As Keizer claims:

Morrison invokes the practices of verbal and musical improvisation as a sign and expressions of African-American selfhood and agency. As Morrison herself has said "black Americans were sustained and healed and nurtured by the translation of their experience into art and above all in music." (1999, p. 106)

This part will shed light on the effect of the figures of speeches, rhythm and tone as the semiotic aspects of language and its influence on the meaning and the structure of the text that is related to the symbolic aspect of language.

\section{AlLiteration, REPETITION, RHYTHM, AND ONOMATOPOEIA}

Morrison's novel is very rhythmical as if the words want to escape the page and start to dance. "For Morrison, African-American writing fundamentally relies on the sounds and rhythms of black music as a source of narrative content, but also as an aesthetic "mirror"” (Eckstein, 2006, p. 272). "The song, laughter and the different words suggest the primordial mother tongue of the preoedipal realm, the maternal semiotic that exists outside of, and in opposion to the symbolic language of the father" (O' Reilly, 2004, p. 89). Moreover, "music expresses the unspeakable and frightening abject, the thing that language leaves out" (Iannetta, 2002, p. 249). From the very beginning, the novel starts with three short sentences "124WAS SPITEFUL. Full of a baby's venom. The women in the house knew it and so did the children" (2004, p. 3). With such an opening, the reader is curious to know more about the house and its venom. These sentences are short and musical and allow the reader to understand something about the setting and the place. Then s/he grasps that a baby ghost that is excorcised by the inhabitants of the house haunts the house. "Come on. Come on. You may as well come on" with such rhythmical invitations, the inhabitants want to catch the ghost (2004, p. 4). The repeated phrase "come on," gives the opportunity to the reader to understand that the inhabitants are not happy with the ghost's presence in their house.

A bit later, Sethe explains that the ghost does not react to their invitation to present itself, as "she wasn't even two years old when she died. Too little to understand. Too little to talk much even" (2004, p. 5). The repeated "too little" not only adds to the musicality of the text, but also shows that the ghost is a baby ghost. Moreover, it shows that Sethe somehow sympathizes with the ghost.

Sethe explains how she escaped Sweet Home, her master's house, and on the way:

The plash of water, the sight of her shoes and stockings awry on the path where she had flung them; or Here Boy lapping in the puddle near her feet, and suddenly there was Sweet Home rolling, rolling, rolling out before her eyes, and although there was not a leaf on that farm that did not make her want to scream, it rolled itself out before her in shameless beauty. (2004, p. 7)

"The plash" is onomatopoeia, and the semiotic, as the child is not able to use words in the semiotic chora, he just imitates its surrounding and "the plash" is the sound of the water. Besides, the repetition of "rolling" in the text makes it poetical and adds to the sound effect of the text.

As Morrison uses the stream of consciousness to render the detailed acount of slavery, the characters live in the present but they talk about their past. The narrator explains that in Sweet Home "all in their twenties, minus women, fucking cows, dreaming of rape, thrashing on pallets, rubbing their thighs and waiting for the new girl" the repetition of "ing," the gerunds, in the text emphasizes slaves' habitual life and the way they did things all their life without even a change (2004, p. 15).

Sethe has given the account of her experience and the way she escaped Sweet Home to Paul D. Then, they go to sleep in the same room. Denver is jealous of Paul D's presence and thinks that her mother's love will vanish with his presence. Therefore, she ate the jelly "slowly, methodically, miserable" (2004, p. 23). The adverbs intensify her manner and her perturbed mind and her loneliness.

With Paul D's presence, everything comes to its order and all the characters remember their past as it is mentioned "drabness looked drab; heat was hot" with such a melodic and short sentences, the author shows the influence of Paul D's presence on people's lives (2004, p. 48).

Little rice, little bean,

No meat in between.

Hard work ain't easy,

Dry bread ain't greasy....

Lay my bead on the railroad line,

Train come along, pacify my mind.

If I had my weight in lime,

I'd whip my captain till he went stone blind.

five-cent nickel,

Ten-cent dime,

Busting rocks is busting time. (2004, p. 48)

These two stanzas are not only symbolic and have their own formal and grammatical structure but also they are semiotic as they have rhythm and melody. 
Poetic language works precisely by undermining the structures that usually characterise textual expression-as AnneMarie Smith puts it, poetic language "is defined by its infringement of the laws of grammar and prose." The function of poetry is to create, to "make it new," and this creating must come from drives outside the prosaic, the structured, the symbolic. (Stokes-king, 2006, p. 43)

Even the repetition of "pounding" in the sentence "the songs he knew from Georgia were flat-headed nails for pounding and pounding and pounding" refers to the repetitious job they had to do each moment of their life (2004, p.48). In Kristevan terms, poetry is assertion of the semiotic within the symbolic, an interaction that determines the type of discourse. "Poetry highlights the thetic stage while advancing the fundamental importance of the semiotic" (Sutcliffe, 2003, p. 346).

As Paul D and Sethe share their memories, they talk about Denver and her behavior, but Sethe believes that nothing can hurt her as "everybody" she knows "dead or gone or dead or gone" but Denver is alive and nothing can hurt her (2004, p. 50). Through the musical sentences, Sethe indicates her assurance and, besides, she expresses her sense of loss She has lost all the people she loved, but she is sure that Denver will not be hurt. Paul D is worried that Denver is sad and feels lonely; therefore, he decides to take them to the carnival, there "the black people in its audience thrill upon thrill upon thrill" and they enjoy their time (2004, p. 58). The repetition of "thrill" shows their inner satisfaction. They enjoy the carnival as it is held just for the black and they can enjoy it because they are together.

When they return home, they observe a young woman stand in front of their house. They invite her home and ask some questions about the place she has come from and the family she has had. The young woman with the repetitious word "long way" highlights the long distance she has walked to arrive at 124 (2004, p. 77). Paul D thinks that he has seen Beloved, the newly arrived young woman, somewhere and with such an impression, he remembers his past when he should "Move. Walk. Run. Hide. Steal and move on" as quick as the words appear on the page (2004, p. 78). These words are both semiotic and symbolic as they not only have grammatical structures, but also show the restless life Paul $\mathrm{D}$ has had as a slave.

As Paul D remembers his past, he explains that one day he saw Halle, Sethe's husband, who had stood still and could not move. Before Paul D remembers this scene, he finds out that two boys have stolen Sethe's milk and he discovers why Halle was so shocked. When Sethe realizes Halle has seen the event, but has not reacted, she walks "up and down, up and down" in the room and these repetitious words reflect her fury and rage $(2004$, p. 81$)$. She is irritated that her husband acted so foolishly. As Deutrich mentions, "repetition reinforces the horror of the images and is characteristic of oral expression" (2004, p. 32).

One night, in order to talk to Sethe, Paul D goes after Sethe to find her in the restaurant, where she works, "when she saw him, she said Oh, and her smile was both pleasure and surprise" the "oh" sound semiotically expresses Sethe's surprise and happiness (2004, p. 149). He reveals his secret and tells her that he wants her to be pregnant. They sleep with each other and "Paul D's chest rose and fell, rose and fell under her hand" (2004, p. 156). As his sexual impulses arouse, the rhythm of the text reflects his desires. Next day Sethe remembers Sweet Home and Mr. Garner. Mr. Garner believed that the city has all the facilities such as "iron stoves, buttons, ships, shirts, hairbrushes, paint, steam engines, books" the alliteration of [S] sound presents the calm atmosphere they have enjoyed in this city (2004, p. 168). Unlike the facilities for the whites, the city has provided misery for the blacks.

Whole towns wiped clean of Negroes; eighty-seven lynching in one year alone in Kentucky; four colored schools burned to the ground; grown men whipped like children; children whipped like adults; black women raped by the crew; property taken, necks broken. He smelled skin, skin and hot blood. The skin was one thing, but human blood cooked in a lynch fire was a whole other thing. (emphasis added, 2004, p. 212)

The repetition of "skin, blood" and "lynch" not only makes it musical but also indicates the disaster; it displays the racist society and emphasizes the whites' misbehavior. In addition, Beloved remembers her past and the way the whites tortured the blacks:

I cannot find my man the one whose teeth I have loved a hot thing the little hill of dead people a hot thing the men without skin push them through with poles the woman is there with the face I want the face that is mine they fall into the sea which is the color of the bread she has nothing in her ears if I had the teeth of the man who died on my face I would bite the circle around her neck bite it away I know she does not like it now there is room to crouch and to watch the crouching others it is the crouching that is now always now inside the woman with my face is in the sea a hot thing. (emphasis added, 2004, p. 212)

Repetition of the "hot thing," "face" and "skin" indicates the great suffering the blacks should have endured in the white racist society.

The black community wants to free Sethe from Beloved; therefore, they stand in front of 124 and sing a song "yes, yes, yes, oh yes. Hear me. Hear me. Do it, Maker, do it. Yes" (2004, p. 304-305). The repeated "yes" manifests that the women encourage Sethe to leave 124 and join them. Tally says that the sound that the community of women produces "is intimidated to be the pre-verbal sound of human origin before language" (2004, p. 45). As they sing a song, it seems that "In the beginning there were no words. In the beginning was the sound, and they all knew what that sound sounded like" (2004, p. 305). As the child uses semiotic impulses and imitates his/her surrounding then enters the realm of language, the narrator highlights the process in the above sentence. In the narrator's words, in the beginning, the sounds existed and then the words came into existence. At first, the Africans learn to sing and then they understand to express 
their suffering through language. Beloved is disappointed that her mother leaves her for the second time and just states: "No no. Nonono" and it shows the deep sadness she feels when she loses her mother for the second time (2004, p. 309). At last, Beloved disappears.

\section{METAPHOR, SIMILE, METONYMY AND COLOR IMAGERY}

Sometimes characters use simile and metaphor or metonymy in order to equivocate. As the truth may displease other persons, they hide it and say it implicitly. The figurative language is part of the semiotic aspect of language, even "structural linguistics, operating on phonological oppositions, or on two axes of metaphor and metonymy, accounts for some of the articulation, operating in what we have called the semiotic" (Kristeva, 1984, p. 41). In some parts of the novel, one can trace these features. As Sethe wants to forget about her past, she likens the picture of the men who came to nurse her to her "lifeless" "nerves" $(2004$, p. 6). Both of them are without affection and neither of them can understand her emotions. In the conversation between Paul D and Sethe, Sethe relieves Paul D and assures him that Baby Suggs' death was "soft as cream" and not painful at all $(2004$, p. 8).

Then Sethe likens Mrs. Garner's disease metaphorically to "lump in her neck the size of a sweet potato" to lessen the effect of the horrible disease she had (2004, p. 10). In the same way, the white girl compares Sethe's wounded back to a "choke cherry" tree not to shock Sethe (2004, p. 18). Moreover, Paul D compares it to "a decorative work of an iron smith" (2004, p. 21). He wants to assure Sethe that her back is not as horrible as she thinks. Even the narrator compares Sethe's blood to the roses that "blossomed in the blanket" to visualize the harshness of the matter and at the same time not to horrify Sethe (2004, p. 109).

Sethe remembers her mother and describes her to Beloved figuratively too. Sethe thinks that her mother worked a lot during the week, that on "Sunday she slept like a stick" to indicate her mother's fatigue and drudgery on Sundays (2004, p. 72).

As Stamp Paid informs Paul D that Sethe has killed her daughter, Stamp Paid likens Sethe to a wild animal:

How she flew, snatching up her children like a hawk on the wing; how her face beaked, how her hands worked like claws, how she collected them every which way: one on her shoulder, one under her arm, one by the hand, the other shouted forward into the woodshed filled with just sunlight and shavings now because there wasn't any wood. (2004, p. 185)

He thinks she is as ferocious as animals, and shows great brutality when she killed her daughter. discovering the event, Paul D wants to inform Sethe that he knows what she has committed and Paul D's "marrow" is exhausted. The narrator uses metonymy to show the effect of Paul D's knowledge on Paul D's health and emphasizes that Paul D cannot bear its burden (2004, p. 213).

While Paul D leaves Sethe, she remains alone with Beloved and Beloved tortures her mother. Denver considers her mother as a "ragdoll" because she stands motionless and indifference (2004, p. 286). Denver asks for help and the black neighbors stand in front of 124 and sing a song. As Sethe hears the song she feels "like a baptized in its wash" (2004, p. 308). It seems that she feels innocent again and her guilt melts away.

Besides the metonymy and metaphor, the characters use color imagery and express their feeling through colors. Signification of each color is important in the context that perceiver feels it; therefore, the color and the perceiver's mood have a direct relationship.

Kneeling in the keeping room where she usually went to talk-think it was clear why Baby Suggs was so starved for color. There wasn't any except for two orange squares in a quilt that made the absence shout. The walls of the room were slate-colored, the floor earth-brown, the wooden dresser the color of itself, curtains white, and the dominating feature, the quilt over an iron cot, was made up of scraps of blue serge, black, brown and gray wool--the full range of the dark and the muted that thrift and modesty allowed. In that sober field, two patches of orange looked wild--like life in the raw. (2004, p. 46)

The color imagery and repetition of dark colors show the gloomy and sombre atmosphere of the house. It seems that just death dominates their life.

Paul D hopes that Sethe will not be violent and instead of color "red" "she stuck to blue, yellow, maybe green" as these colors are the colors of caring, kindness, and calmness (2004, p. 213). In addition, "until Beloved story is fully articulated and meaning is made of Sethe's maternal experience, Morrison keeps both contained with in the 'non expressive', non language realm of the chora, manifested through the mysterious pulsing red light that haunts Sethe's house" (Eckard, 2002, p. 70).

As Denver enters the Bodwin's house, she is fascinated with "blue and soft" objects, "peal lamps and emerald house" in general (2004, p. 298). Through the use of colors, one can see how comfortable Denver feels at Bodwins' house.

\section{TONE AND VERBAL IRONY}

Rhythm and tone are parts of the semiotic aspect of language that are meaningful (Thomas, 2008, p. 78). Denver expresses her loneliness at 124 and Paul D defends her but Sethe shots "Paul D a look of snow" and adds "what you care" (2004, p. 17)? The diction and the use of the word "snow" manifest Sethe's angry tone. She never permits anyone to interfere with her affairs. When Beloved arrives and Denver takes the responsibility to take care of her, her love and 
her passion are shown in her words "she's not sick" (2004, p. 63)! She is very sorry that her newly-found friend is sick and she wants to save Beloved's life.

Finding out that Halle has seen her but he has hid himself, Sethe gets angry and the repetition of "he saw? He saw, he saw, he saw" shows how irritated she is that her husband neither killed those who attack his wife, nor defended her (2004, p. 81).

The same as Sethe, Beloved gets angry when she plays with Denver and utters, "Don't tell me what to do. Don't you never never tell me what to do" (2004, p. 89). Her angry tone is reflected in the repetition of the word "never." She wants to manipulate everything and cannot tolerate that someone dominates her.

When Paul D recognizes that Sethe has killed her daughter, he calls her an animal. At the end of the novel, when he returns to help Sethe and to wash her feet, she says "and count my feet" (2004, p. 321)? With such a verbal irony, she takes revenge on Paul D because she believes he cannot understand motherly love.

\section{TRANSGRESSION}

As mentioned before, Julia Kristeva considers the semiotic as the maternal and the symbolic as the paternal aspect of language. Therefore, one can consider the transgression of the father's rules, along with grammatical and punctuation transgression as the semiotic aspects of language.

Baby Suggs gathered people and talked to them. If one considers a priest as the father figure, Baby Suggs transgressed his rules because she "became an unchurched preacher" (2004, p. 102). However, Baby Suggs was not a priest, but people regarded her holy. She took people to the woods in order to redeem them. However, her method was different from the fathers of the church. Instead of preaching, she permitted the people to cry, laugh and dance together and to free their energies. As Habib holds: "religion controls the first aspect in instituting the symbolic order, an institution justifies first by myth and then by science. On the other hand, poetry, music, dance and theater enact transsymbolic jouissance which threatens "the unity of the social realm and the subject"' $(2007$, p. 700$)$. In the semiotic chora, the child is able to laugh, and to move. The movement in the chora is dance-like. With her methods, Baby Suggs blessed them all, but "she did not tell them they were the blessed of the earth, its inheriting meek or its glorybound pure" (2004, p. 103). She did not act like the fathers of the church but her method was very helpful as people could reveal their inner feelings. There was no need to suppress their desires, unlike those concealing their emotions in the church.

Baby Suggs encourages them to claim their body that was stolen from them under the system of slavery. A part of the reclamation ceremony is the former captive's ability to show affects to laugh, weep, and joyously celebrate unnoosed and straighten necks. (Tait, 2008, p. 56)

Eckstein claims that Baby Suggs represents an "Afro-Christian musical tradition," and Paul D represents "the secular tradition of the blues" (2006, p. 275). As he continues, "the blues is an impulse to keep the painful details and episodes of a brutal experience alive in one's aching consciousness to finger its jagged grains to transcend it, not by the consolation of philosophy but by squeezing from it a near tragic, near comic lyricism" (ibid, 275).

As Sethe's mother was going to die, she wanted to inform her daughter how to identify her mother if an accident happened. "Here. Look here. This is your ma'am. If you can't tell me by my face, look here." "... the fingers, nor their nails, nor even..." (2004, p. 207). The phrase "the fingers, nor their nails, nor even" is not grammatical besides it is not meaningful on its own. It is only complete with the previous sentences, but the author uses it as an independent sentence. The author seems to emphasize that the blacks and the whites are the same, and both are human so she uses a dependent sentence as an independent one. However, the only thing that can separate them is the mark of slavery on the black's bodies.

Besides the grammatical transgression, the punctuation irregularities are traceable too. In Beloved's monologue, there is not any punctuation. It seems that the rush of thoughts come to her mind and she wants to express them without missing even one of them. "I AM BELOVED and she is mine" (2004, p. 248). "Her discourse" is elliptical; "that opening pronouncement is the last structure syntactically marked as sentence" (Holloway, 1990, p. 520). She talks about the black people who suffered from slavery, about her mother, and about all the forgotten and unarticulated events. When Beloved was a two year old child, she was killed by her mother, the reason for not being able to use the punctuation or the correct grammar can be her age. Besides, one should notice that Beloved could be the unconscious recollection of the black people; therefore, she can remember the past very well. "I am not separate from her there is no place where I stop her face is my own and I want to be there in the place where her face is and to be looking at it too a hot thing" (2004, p. 248). The "hot thing" refers to the time of slavery and the way the black people were tortured by the whites.

\section{SENSORY IMPRESSIONS AND DREAMS}

The child is able to have sensory impressions as s/he has a tactile relationship with her/his mother. In the novel, there are some examples of sensory impressions.

"Denver's secrets were sweet," "noisome cologne," "the silence was softer," synesthesia is dominant in the previous sentences $(2004$, p. 43$)$. As one can perceive some words are related to the auditory and some are related to the 
gustatory senses; therefore, both auditory and gustatory sensations are juxtaposed here to explain how Denver has enjoyed her life and now she considers them as the best part of her life.

Involuntary memory is presented early on in the novel via sensorial stimuli, and the fact that in five paragraphs reference is made to all five senses is noteworthy:

1) haptic - "She might be hurrying across a field, running practically, to get to the pump quickly and rinse the chamomile sap from her legs. Nothing else would be in her mind. The picture of the men coming to nurse her was as lifeless as the nerves in her back where the skin buckled like a washboard."

2) olfactory - "Nor was there the faintest scent of ink or the cherry gum and oak bark from which it was made."

( $3 \& 4$ ) [haptic], visual, and auditory - "The plash of water, the sight of her shoes and stocking awry on the path where she had fl ung them; or Here Boy lapping in the puddle near her feet, and suddenly there was Sweet Home rolling, rolling, rolling out before her eyes [...] (Beloved: 6); 43)

5) gustatory_ “[Paul D] made a face as though tasting a teaspoon of something bitter.” (Beloved: 7) (Tally, 2007, p.

In addition to sensory impressions, dreams are important in the novel. Dreams reveal the unconscious desires that cannot be expressed in daily speech and they are related to the semiotic aspect of language.

When Amy looks at Sethe's wounded back, she says, “in her dream walker's voice” (2004, p. 93). As she has never seen such a scene, she is shocked that the whites whipped a pregnant woman so cruelly. Therefore, her voice is dreamy as if in reality this cruel action cannot happen. As Mousey emphasizes, Sethe's scar reminds her pain and abuse that not only she but also all the slaves had to endure (2010, p. 7).

Besides, Sethe has a dream about her children and her husband. As she cannot see them in reality, her mind is preoccupied with their thought and they come to her dreams. She is so worried about her sons' condition that she sees "only their parts in trees" and it shows her anxiety. Moreover, she sees "Halle's face between the butter press and the churn swelled larger and larger" which shows her inner anger. She cannot forgive Halle for letting her suffer from the boys' attack: she sees Halle's deformed face in her dream.

\section{CONCLUSION}

To sum up, one should notice that the writer does not convey the meaning just through language, but sometimes she expresses the characters' intentions through tone, and all the mentioned methods. As it is hard for the characters to express their thoughts explicitly, they use different techniques such as repetition, metaphor, etc to communicate their thoughts.

\section{ACKNOWLEDGMENT}

I would like to thank the following people whose help made the completion of this article possible. I am deeply indebted to Dr. Helen Ouliaei Nia for her enlightening ideas. I would also like to express my deepest gratitude to Dr. Hossein Pirnajmuddin for his gracious advice. Moreover, I also express my gratitude to Kayvan Tahmasebian for his helpful suggestions. I have really benefited from his knowledge and encouragement. Moreover, I express my thanks to Dr. Pyeaam Abbasi for his unwavering belief in me. And special thanks to the professors of English department of University of Isfahan and University of Amin for providing an academic atmosphere.

My warmest thanks go to my parents. Their encouragement and support give me strength to follow my dreams and achieve my goals.

I am deeply grateful to all those mentioned and many who have gone unmentioned. I admit that I will never be able to repay them for their generous and helpful companionship.

\section{REFERENCES}

[1] Amian, K. (2008). Rethinking Postmodernism(s). New York: Rodopi. Web. http://library.nu/docs/V0HXPRS6MJ/RethinkingPostmodernismsACharlesS.PeirceandthePragmatistNegotiationsofThomasPyn choncToniMorrisonCandJonathanSafranFoer.PostmodernStudies

[2] Eckard, P. G. (2002). Maternal Body and Voice in Toni Morrison, Bobbie Ann Mason, and Lee Smith. Columbia: University of Missouri Press.

[3] Eckstein, L. (2006). “A Love Supreme: Jazzthetic Strategies in Toni Morrison's 'Beloved'.” African American Review 40.2.: 271-283. Retrieved in 6 April 2010. Web. http://www.jstor.org/stable/40033715

[4] Habib, M. A. R. (2007). A History of Literary Criticism and Theory: From Plato to the Present. United Kingdom: WileyBlackwell. Print.

[5] Holloway, K. F. C. (1990). "Beloved: A Spiritual." Callaloo 13.3.: 516-525. Retrieved in 30 October 2010. Web. http://www.jstor.org/stable/2931334

[6] Iannetta, M. E. (2002). Literary melancholia, or the refusal to mourn: Amnesia and anamnesis. Memories of love, loss, and abjection in feminine writing. Diss. University of California, Santa Cruz. Dissertations \& Theses: Full Text, ProQuest. Web. 6 Aug. 2011.

[7] Iasevoli, D. (1998). “A Hot Thing: Working on Toni Morrison's Beloved.” English Education 31.1.: 60-61. Retrieved in November 2010. Web. http://www.jstor.org/stable/40172963 
[8] Jones, A. R. (1984). “Julia Kristeva on Femininity: The Limits of a Semiotic Politics." Feminist Review 18: 56-73. Retrieved in October 2010. Web. http://www.jstor.org/stable/1394859

[9] Jung, S. (2009). Dialogism and multiculturalism in the work of Morrison, Silko, Anzaldua, and Vizenor. Diss. The University of Wisconsin - Milwaukee. Dissertations \& Theses: Full Text, ProQuest. Web. 6 Aug. 2011.

[10] Keizer, A. R. (1999). "Beloved: Ideologies in conflict, improvised subjects. "African American Review 33.1 : 105123. Academic Research Library, ProQuest. Web. Retrieved in 6 Aug. 2011.

[11] Kristeva, J. (1984). Revolution in Poetic Language. New York: Columbia University Press.

[12] Morrison, T. (2004). Beloved. USA: Vintage Books.

[13] Mounsey, C. (2010). Nathaniel Hawthorne and Toni Morrison: Multiple interpretations in "The Scarlett Letter" and "Beloved". Diss. Long Island University, The Brooklyn Center. Dissertations \& Theses: Full Text, ProQuest. Web. 6 Aug. 2011.

[14] Mounsey, C. (2010). Nathaniel Hawthorne and Toni Morrison: Multiple interpretations in "The Scarlett Letter" and "Beloved". Diss. Long Island University, The Brooklyn Center. Dissertations \& Theses: Full Text, ProQuest. Web. 6 Aug. 2011.

[15] O'Reilly, A. (2004). Toni Morrison and Motherhood, a Politics of the Heart. USA: University of New York Press. Web. http://library.nu/docs/GEZBLKTDYX/ToniMorrisonandMotherhoodAAPoliticsoftheHeart

[16] Peterson, N. J. (2008). Beloved Character Studies. Great Britain: MPG Books.

[17] Sabo, P. (2010). Impossible mourning: Lamentations as a text of melancholia. Diss. University of Alberta (Canada). Dissertations \& Theses: Full Text, ProQuest. Web. 6 Aug. 2011.

[18] Stokes-King, L. (2006). "Lovely shapes and sounds intelligible": Kristevan semiotic and Coleridge's language of the unconscious. Diss. McGill University (Canada). Dissertations \& Theses: Full Text, ProQuest. Web. 6 Aug. 2011.

[19] Sutcliffe, B. M. (2003). "Reading the Kristevan Semiotic and Symbolic: Nina Sadur's "Kol'tsa" and Marina Kulakova's "Reka po imeni Master". " Canadian Slavonic Papers 45.3/4 : 337. Academic Research Library, ProQuest. Web. 6 Aug. 2011.

[20] Tait, A. (2008). Redefining women's beauty through Toni Morrison: A black feminist reading. Diss. Morgan State University. Dissertations \& Theses: Full Text, ProQuest. Web. 6 Aug. 2011.

[21] Tally, J. (2007). The Cambridge Companion to Toni Morrison. UK: Cambridge University Press.

[22] Thomas, K. (2008). The Lazarus crisis: Subjectivity, language and sacrifice in cultural narratives. Diss. State University of New York at Stony Brook. Dissertations \& Theses: Full Text, ProQuest. Web. 6 Aug. 2011.

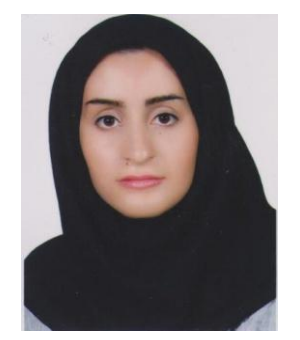

Camelia Talebian Sadehi was born in Ahwaz, Iran in 1987. She studied English literature and got her B.A. from University of Isfahan, Iran in 2009. Then, she continued the same major in M.A. and got her degree from University of Isfahan in 2011. She published two articles "The Melancholic Subject and The Bluest Eye" and "Beloved and Kristevan Melancholic Subject". She also attended some national and international conferences and presented her lectures. She is lecturer at University of Amin, Isfahan, Iran, and teaches English literature. 